\title{
Pengaruh Limbah Karbit / Calcium Carbit Sebagai Bahan Substitusi Semen Pada Beton
}

\author{
Liberty Juniasy Somalinggi ${ }^{\star 1}$, Frans Phengkarsa ${ }^{\star 2}$, Lisa Febriani ${ }^{\star 3}$, \\ *1 Mahasiswa Program Studi Teknik Sipil, Universitas Kristen Indonesia Paulus, Makassar \\ Email libertyjuniasy@gmail.com \\ *2 Dosen Program Studi Teknik Sipil, Universitas Kristen Indonesia Paulus, Makassar \\ Email fphengkarsa@hotmail.com \\ *3 Dosen Program Studi Teknik Sipil, Universitas Kristen Indonesia Paulus, Makassar \\ Email lisa@ukipaulus.ac.id
}

\begin{abstract}
ABSTRAK
Penelitian ini memanfaatkan limbah karbit sebagai pengganti sebagian semen dalam pembuatan beon yang bertujuan untuk mengetahui nilai optimum penambahan limbah karbit yang berfungsi sebagai pengganti sebagian semen terhadap kuat tekan, kuat tarik belah, dan modulus elastisitas beton. Variasi limbah karbit sebesar 0\%, 4\%, 6\%, dan $8 \%$. Sampel yang digunakan adalah silinder dengan diameter $15 \mathrm{~cm}$ dan tinggi $30 \mathrm{~cm}$ sebanyak 72 sampel. Pengujian kuat tekan dilakukan pada umur 3 hari, 7 hari, 14 hari, 21 hari, dan 28 hari, dan kekuatan tarik belah dan modulus elastisitas diuji pada umur 28 hari. Hasil pengujian bahan limbah karbit 0\% menunjukkan kuat tekan 35,47 MPa, kuat tarik belah 2,59 $\mathrm{MPa}$, dan modulus elastisitas 16957,76 MPa. Variasi 4\% limbah karbit, kuat tekan $37.64 \mathrm{MPa}$, kuat tarik belah 2,66 MPa, dan modulus elastisitas 17180,87 MPa. Variasi $6 \%$ limbah karbit, kuat tekan $33.60 \mathrm{MPa}$, kuat tarik belah 2,50 MPa, dan modulus elastisitas $16635,53 \mathrm{MPa}$. Variasi $8 \%$ limbah karbit, kuat tekan $35.48 \mathrm{MPa}$, kuat tarik belah 2,50 MPa, dan modulus elastisitas $16429,19 \mathrm{MPa}$. Hasil penelitian menunjukkan bahwa beton dengan $4 \%$ limbah karbit mendapatkan hasil uji paling optimum untuk semua pengujian.
\end{abstract}

Kata Kunci : Limbah Karbit, Kuat Tekan, Kuat Tarik Belah, dan Modulus Elastisitas

\begin{abstract}
This study utilizes carbide waste as a partial substitute for cement in the manufacture of beons which aims to determine the optimum value of adding carbide waste which functions as a partial cement substitute for compressive strength, split tensile strength, and modulus of elasticity of concrete. Variations of carbide waste are $0 \%, 4 \%, 6 \%$, and $8 \%$. The sample used was a cylinder with a diameter of $15 \mathrm{~cm}$ and a height of $30 \mathrm{~cm}$ as many as 72 samples. The compressive strength test was carried out at the age of 3 days, 7 days, 14 days, 21 days, and 28 days, and the split tensile strength and modulus of elasticity were tested at the age of 28 days. The results showed that the concrete with $4 \%$ carbide waste obtained the optimum test results for all tests.
\end{abstract}

Keywords: Carbide Waste, Compressive Strength, Tensile Strength, and Modulus of Elasticity

\section{PENDAHULUAN}

Saat ini, ketika teknologi di berbagai bidang mengalami perubahan pesat, sektor industri juga berkembang pesat. Semakin banyak aktivitas industri yang terjadi maka limbah industri juga akan bertambah dan menimbulkan masalah. Apalagi di Indonesia, pengelolaan limbah kurang mendapat perhatian sehingga menimbulkan banyak pencemaran.

Salah satu upaya pencegahan yang dilakukan di zaman sekarang yaitu peneliti menginovasikan dan mengganti bahan dasar campuran beton. Oleh karena itu, untuk meningkatkan kualitas beton itu sendiri dan meningkatkan nilai ekonomis dan ramah lingkungan dari material yang tidak terpakai seperti limbah karbit, inovasi beton saat ini sedang mengalami perkembangan yang cukup pesat yaitu reuse dan reduce material yang tidak terpakai atau penambahan bahan tambahan.

Limbah karbit merupakan sisa pembakaran karbit yang tidak digunakan atau dibuang begitu saja. Sampah karbit jenis ini mempunyai sifat fisik berupa serbuk, yaitu berwarna abu-abu pada kondisi lembab, berwarna putih pada kondisi kering, berbau menyengat, dan tidak larut. Limbah ini diperoleh dari 
Paulus Civil Engineering Journal

E- Jurnal Teknik Sipil UKI-Paulus Makassar http://ojs.ukipaulus.ac.id/index.php/pcei
Volume 2 No.4, Desember 2020

ISSN Online : $x x x x-x x x x$ industri pengelasan di bengkel las karbit dan tidak digunakan secara efektif, sehingga menyebabkan kerusakan lingkungan. Komposisi kimiawi limbah karbit adalah $\mathrm{CaO}, \mathrm{SiO}_{2}, \mathrm{Fe}_{2} \mathrm{O}_{3}, \mathrm{Al}_{2} \mathrm{O}_{3}$. Dari senyawa yang ada limbah karbit atau kapur buangan industry acetilin digolongkan dalam jenis kapur padam yang banyak mengandung $\mathrm{CaO}$, dimana $\mathrm{CaO}$ ini merupakan bahan dasar dalam pembuatan semen sebesar 60\%-65\% yang berasal dari batu kapur [1]. Dengan begitu, maka limbah karbit hasil pengelasan dapat digunakan sebagai semen pada campuran beton.

Limbah karbit merupakan produk gas asetilen. Gas ini digunakan di seluruh dunia untuk penerangan, pengelasan, pemotongan besi dan pematangan buah. Semen karbida dibuat melalui proses yang sangat sederhana. Kalsium karbida $\left(\mathrm{CaC}_{2}\right)$ dan air $\left(\mathrm{H}_{2} \mathrm{O}\right)$ bereaksi menghasilkan gas asetilen $\left(\mathrm{C}_{2} \mathrm{H}_{2}\right)$ kalsium hidroksida $\mathrm{Ca}(\mathrm{OH})_{2}$ [2]. Kalsium karbit produk sampingan dari menghasilkan gas asetilen, adalah padatan putih hitam atau abu-abu. Awalnya karena adanya gas dan air, limbah karbida dihasilkan dalam bentuk koloid (semi cair). Setelah 3-7 hari, gas yang terkandung menguap perlahan saat gas menguap, dan limbah karbit kapur mulai mengering dan menjadi potongan yang rapuh dan rapuh, dan dapat menjadi bubuk.

Limbah karbit atau kapur buangan industri acetilin digolongkan dalam jenis kapur padam yang banyak mengandung $\mathrm{CaO}$, dimana $\mathrm{CaO}$ ini merupakan bahan dasar dalam pembuatan semen sebesar 60\%-65\% dan bahan dasar lainnya seperti silika, alumina, dan oksida besi [2].

Tabel 1. Kandungan limbah karbit

\begin{tabular}{cc}
\hline Komposisi Kimia & Kandungan \% \\
\hline $\mathrm{SiO}_{2}$ & 4,3 \\
$\mathrm{Fe}_{2} \mathrm{O}_{3}$ & 0,9 \\
$\mathrm{Al}_{2} \mathrm{O}_{3}$ & 0,4 \\
$\mathrm{CaO}$ & 56,5 \\
$\mathrm{MgO}$ & 1,7 \\
$\mathrm{SO}$ & 0,06 \\
$\mathrm{LOI}$ & 36,1 \\
\hline
\end{tabular}

Penelitian ini dilakukan dengan memanfaatkan limbah karbit sebagai pengganti sebagian semen pada campuran beton. Pemanfaatan limbah karbit ini dapat mengurangi kerusakan lingkungan dan dapat mengurangi penggunaan semen portland pada campuran beton.

Penelitian yang meneliti masalah karbit antara lain Pengaruh Substitusi Limbah Karbit Terhadap Karakteristik Beton". Pada penelitian ini komposisi perbandingan limbah karbit yang digunakan yaitu $5 \%$, $10 \%, 15 \%$, dan $20 \%$, dengan mutu beton f'c 25 Mpa.

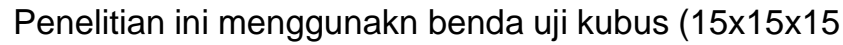
$\mathrm{cm})$. Hasil penelitian ini diperoleh nilai kuat tekan optimum terjadi pada penambahan persentase limbah karbit $5 \%$ dan mengalami penurunan pada variasi persentase $10 \%-20 \%$ [3].

Pemanfaatan Limbah Karbit Sebagai Pengganti (Substitusi) Semen Pada Pembuatan Beton Ringan

Seluler (Cellular Lightwight Concrete). Pada penelitian ini variasi persentase limbah karbit yang digunakan adalah $0 \%, 1 \%, 2 \%, 3 \%$ dan $4 \%$ terhadap berat benda uji. Hasil penelitian dengan penambahan limbah las karbit menunjukkan bahwa kuat tekan beton mengalami peningkatan sebesar $1 \%-2 \%$. Dengan kuat tekan optimum pada variasi $2 \%$, namun mengalami penurunan pada variasi $3 \%$ dan $4 \%$ [4].

Tujuan dari penelitian ini adalah (1) mengetahui jumlah presentase pemakaian limbah karbit dan pengaruhnya sebagai pengganti sebagian semen terhadap kuat tekan, kuat tarik belah, dan modulus elastisitas beton. (2) memperoleh komposisi campuran beton yang optimum dengan menggunakan limbah karbit sebagai bahan pengganti sebagian semen terhadap kuat tekan, kuat tarik belah, dan modulus elastisitas beton.

\section{METODE}

Lokasi pengambilan limbah karbit berada di salah satu bengkel las mobil yang terletak di Kota Makassar, Provinsi Sulawesi Selatan, dan tempat pengambilan agregat halus (pasir) dan agregat kasar berasal dari sungai Jeneberang, kabupaten Gowa, Sulawesi Selatan. Penelitian dilaksanakan di Laboratorium Struktur dan Material Jurusan Teknik Sipil Fakultas Teknik Universitas Kristen Paulus Indonesia Makassar. Jenis penelitian eksperimental di laboratorium ini adalah menguji karakteristik agregat dan limbah karbida, menguji kuat tekan, kuat tarik belah, kuat lentur dan modulus elastisitas beton.

\section{Karakteristik Agregat}

Agregat adalah partikel mineral alami yang berperan sebagai pengisi dalam mortar atau campuran beton [5]. Grading agregat ini harus sedemikian rupa sehingga seluruh balok beton dapat bertindak sebagai benda padat, homogen dan padat, dengan agregat kecil bertindak sebagai celah antara agregat besar [6]. Ada dua jenis agregat:

\section{Agregat Halus}


Agregat halus bisa berupa pasir alam, pasir olahan atau kombinasi dua jenis pasir. Bentuk agregat halus mempengaruhi kualitas beton yang akan diproduksi, rongga terkecil pada agregat bulat berukuran $33 \%$ lebih kecil dibandingkan jenis rongga lainnya. [7]

Agregat halus yang digunakan dalam campuran harus terdiri dari partikel tajam dan keras yang tidak dapat dihancurkan atau dipecahkan oleh cuaca (seperti panas matahari dan hujan). Kandungan sludge yang terkandung dalam agregat halus tidak boleh melebihi $6 \%$, jika kandungan sludge melebihi $6 \%$ maka harus dicuci. Berat jenis dan penyerapan agregat, semakin tinggi nilai Berat jenis, semakin rendah laju serapannya. agregat halus adalah agregat dengan ukuran partikel maksimum 5,00 $\mathrm{mm}$.

Kekasaran pasir dibedakan menjadi empat kelompok, yaitu zona 1 (zona 1), zona 2 (zona 2), zona 3 (zona 3), zona 4 (zona 4), di antaranya zona 1 Pasir di bagian tengah lebih kasar, pasir di area 2 lebih tebal, pasir di area 3 pasir halus, dan pasir di area 4 pasir halus [8]

Tabel 2. Syarat gradasi agregat halus

\begin{tabular}{|c|c|c|}
\hline \multicolumn{2}{|c|}{$\begin{array}{l}\text { Ukuran Saringan } \\
\quad(\mathrm{mm})\end{array}$} & $\begin{array}{l}\text { Zona } 1 \\
\text { (kasar) }\end{array}$ \\
\hline & 100 \\
\hline \multirow{2}{*}{\multicolumn{2}{|c|}{$\begin{array}{l}4,80 \\
2,40\end{array}$}} & $90-100$ \\
\hline & & $60-95$ \\
\hline \multicolumn{2}{|l|}{1,20} & $30-70$ \\
\hline \multicolumn{2}{|l|}{0,60} & $15-34$ \\
\hline \multicolumn{2}{|l|}{0,3} & $5-20$ \\
\hline \multicolumn{2}{|l|}{0,15} & $0-10$ \\
\hline \multicolumn{3}{|c|}{ Tabel 3. Spesifikasi karakteristik agregat halu } \\
\hline $\begin{array}{c}\text { Karakteristik } \\
\text { agregat halus }\end{array}$ & $\begin{array}{c}\text { Interval } \\
\text { batas }\end{array}$ & Pedoman \\
\hline $\begin{array}{l}\text { Kadar organik, } \\
\text { warna }\end{array}$ & $<$ No.3 & SNI 2816-2014 \\
\hline Kadar air, \% & $3,0-5,0$ & SNI 03-1971-2011 \\
\hline $\begin{array}{l}\text { Berat volume } \\
\text { padat, } \mathrm{kg} / \mathrm{ltr}\end{array}$ & $1,40-1,90$ & SNI 03-4804-1998 \\
\hline $\begin{array}{l}\text { Berat volume } \\
\text { gembur, } \mathrm{kg} / \mathrm{tr}\end{array}$ & $0,20-2,00$ & SNI 03-4804-1998 \\
\hline Penyerapan,\% & $0,20-2,00$ & SNI 1970-2008 \\
\hline $\begin{array}{l}\text { Berat jenis } \\
\text { (SSD) }\end{array}$ & $1,6-3,2$ & SNI 1970-2008 \\
\hline $\begin{array}{l}\text { Modulus } \\
\text { kehalusan }\end{array}$ & $2,20-3,10$ & SNI 03-1968-1990 \\
\hline
\end{tabular}

\section{Persen yang Lolos (\%)}

\begin{tabular}{ccc}
$\begin{array}{c}\text { Zona 2 } \\
\text { agak kasar) }\end{array}$ & $\begin{array}{c}\text { Zona 3 } \\
\text { (Agak Halus) }\end{array}$ & $\begin{array}{c}\text { Zona 4 } \\
\text { (halus) }\end{array}$ \\
100 & 100 & 100 \\
$90-100$ & $90-100$ & $95-100$ \\
$75-100$ & $85-100$ & $95-100$ \\
$55-100$ & $75-100$ & $90-100$ \\
$35-59$ & $60-79$ & $80-100$ \\
$8-30$ & $12-40$ & $5-50$ \\
$0-10$ & $0-10$ & $0-15$ \\
\hline
\end{tabular}

\section{Agregat Kasar}

\begin{tabular}{cccc}
\hline 19 & $35-70$ & $95-$ & 100 \\
9,6 & $10-40$ & $30-60$ & $50-85$ \\
4,8 & $0-5$ & $0-10$ & $0-10$ \\
\hline
\end{tabular}

Tabel 5. Spesifikasi karakteristik agregat kasar.

\begin{tabular}{lcc}
\hline $\begin{array}{c}\text { Karakteristik } \\
\text { Agregat Kasar }\end{array}$ & $\begin{array}{c}\text { Interval } \\
\text { Batas }\end{array}$ & Pedoman \\
\hline Kadar air, \% & $0,5-2,0$ & SNI 03-1971- \\
& & 2011 \\
Berat volume & $1,40-1,90$ & SNI 03-4804- \\
padat, kg/ltr & & 1998 \\
Berat volume & $1,40-1,90$ & SNI 03-4804- \\
gembur, kg/tr & & 1998 \\
Penyerapan,\% & $0,20-2,00$ & SNI 1969-2008 \\
Berat jenis SSD & $1,60-3,20$ & SNI 1969-2008 \\
\hline
\end{tabular}

\section{Kuat Tekan Beton (Berdasarkan SNI 1974-2011)}

Kuat tekan beton adalah besarnya beban per satuan luas, yang menyebabkan benda uji beton hancur dibebani dengan gaya tekan tertentu yang dihasilkan oleh mesin tekan [9].

Perhitungan kuat tekan beton digunakan persamaan

Tabel 4. Analisa Saringan Agregat Kasar

\begin{tabular}{cccc}
\hline $\begin{array}{c}\text { Ukuran } \\
\text { Saringan } \\
(\mathrm{mm})\end{array}$ & \multicolumn{3}{c}{ Persentase Lolos (\%) } \\
Gradasi Agregat & 20 & 10 \\
76 & $40 \mathrm{~mm}$ & $\begin{array}{c}20 \\
\mathrm{~mm}\end{array}$ & $\mathrm{~mm}$ \\
\hline 38 & 95100 & - & - \\
\hline
\end{tabular}

$\frac{P}{A}$

Keterangan :

$P=$ Beban maksimum $(\mathrm{N})$

$A=$ Luas penampang benda uji $\left(\mathrm{mm}^{2}\right)$ 
Paulus Civil Engineering Journal

E- Jurnal Teknik Sipil UKI-Paulus Makassar

http://ojs.ukipaulus.ac.id/index.php/pcei

Mekanisme uji kuat tekan beton ditunjukkan pada Gambar 1.

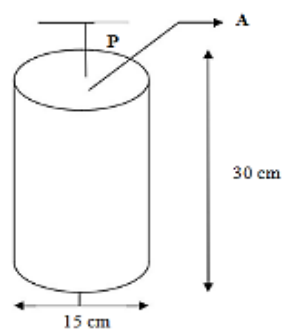

Gambar 1. Uji kuat tekan

3. Kuat Tarik Belah Beton (Berdasarkan SNI 2491:2014)

Kuat tarik belah adalah kuat tarik beton yang ditentukan berdasarkan kuat tarik belah silinder beton yang dipadatkan pada sisi panjangnya. Kuat tarik beton rendah, dan kuat tekan beton tidak sebanding dengan kuat tarik belah [10].

Tegangan tarik yang dihasilkan saat benda uji tarik belah disebut kekuatan silinder belah yang dihitung dengan rumus (2) melalui mekanisme pengujian yang ditunjukkan pada Gambar 2.

$T=\frac{2 P}{\pi l d}$

Dimana :

$\mathrm{T}=$ Kekuatan tarik belah $(\mathrm{N} / \mathrm{mm}, \mathrm{MPa})$

$\mathrm{P}=$ Kapasitas beban $(\mathrm{N})$

$\mathrm{L}=$ Panjang sampel $(\mathrm{mm})$

$\mathrm{D}=$ Diameter sampel $(\mathrm{mm})$
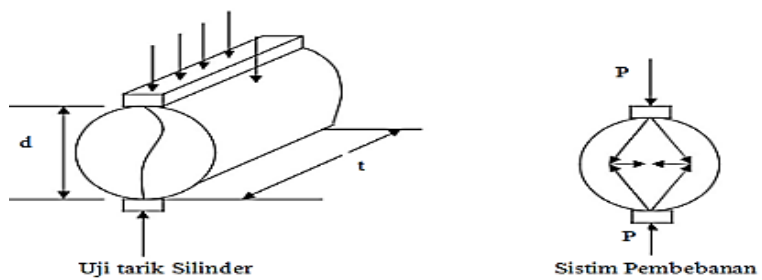

Tabel 6. Komposisi kebutuhan bahan campuran beton Untuk $1 \mathrm{~m}^{3}$

Berat $(\mathrm{kg})$

Limbah

Karbit

Semen

Air

Agregat Halus

Agregat Kasar

Limbah Karbit

\begin{tabular}{lllllc}
\hline $0 \%$ & 357,41 & 193 & 576,58 & 1192,17 & 0 \\
$4 \%$ & 343,11 & 193 & 576,58 & 1192,17 & 14,30 \\
$6 \%$ & 335,96 & 193 & 576,58 & 1192,17 & 21,44 \\
$8 \%$ & 328,81 & 193 & 576,58 & 1192,17 & 28,60 \\
\hline
\end{tabular}

HASIL DAN PEMBAHASAN

Agregat Halus
Volume 2 No.4, Desember 2020

ISSN Online : $x x x x-x x x x$
4. Modulus Elastisitas Beton

Modulus elastisitas adalah ukuran kekakuan atau ketahanan terhadap deformasi suatu bahan. Modulus elastisitas ditentukan oleh perubahan tegangan relatif terhadap regangan dalam batas elastis.

Standar untuk pengujian modulus elastisitas mengacu pada ASTM C 469-02 "Standard Test Method for Static Modulus of Elasticity and Poisson's Ratio of Concrete in Compression". Rumus untuk menghitung modulus elastisitas adalah:

E $\frac{S_{2}-S_{1}}{\varepsilon_{2}-0,00005}$

\section{Dengan:}

us elastisitas beton (MPa)

$S_{1}=$ Besar tegangan saat regangan $0,00005(\mathrm{MPa})$

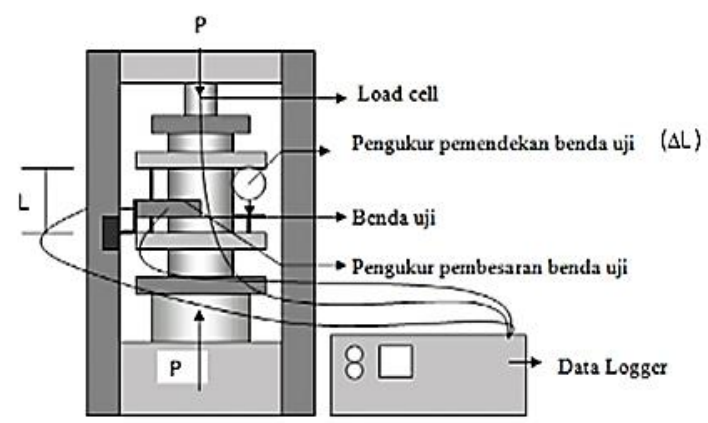

Gambar 3. Pengujian modulus elastisitas beton

5. Pembuatan Benda Uji

1. Karakteristik Agregat 
Tabel 6. Hasil pengujian agregat halus

\begin{tabular}{|c|c|c|}
\hline \multicolumn{2}{|c|}{ Karakteristik } & \\
\hline \multirow{2}{*}{\multicolumn{2}{|c|}{ Kadar Air }} & 4,058 \\
\hline & Kadar Organik & \\
\hline \multicolumn{2}{|c|}{ Kadar Lumpur } & \\
\hline \multicolumn{2}{|c|}{ Berat Jenis SSD } & 2,5 \\
\hline \multicolumn{2}{|c|}{ Absorpsi (Penyerapan) } & 1,31 \\
\hline \multicolumn{2}{|c|}{ Berat Volume Padat } & 1645 \\
\hline \multicolumn{2}{|c|}{ Berat Volume Gembur } & 1573,3 \\
\hline \multicolumn{2}{|c|}{ Modulus Kehalusan } & \\
\hline \multicolumn{3}{|l|}{ Agregat Kasar } \\
\hline \multicolumn{3}{|c|}{ Tabel 7. Hasil pengujian agregat kasar } \\
\hline Karakteristik & Hasil & Interval SNI \\
\hline \multirow{3}{*}{$\begin{array}{c}\text { Kadar lumpur } \\
\text { Kadar air } \\
\text { Berat volume } \\
\text { padat }\end{array}$} & $0,520 \%$ & $0,2-1 \%$ \\
\hline & $0,642 \%$ & $0,5-2,0 \%$ \\
\hline & $\begin{array}{c}1727,77 \\
8 \mathrm{~kg} / \mathrm{ltr}\end{array}$ & $1400-1900 \mathrm{~kg} / \mathrm{tr}$ \\
\hline $\begin{array}{l}\text { Berat volume } \\
\text { gembur }\end{array}$ & 1611,11 & $1400-1900 \mathrm{~kg} / \mathrm{ltr}$ \\
\hline \multirow{2}{*}{$\begin{array}{l}\text { Penyerapan } \\
\text { Berat jenis }\end{array}$} & $1,504 \%$ & $0,20-2,00 \%$ \\
\hline & 2,639 & $1,6-3,2$ \\
\hline
\end{tabular}

\section{Bahan Pengikat}

Tabel 8. Hasil pemeriksaan karakteristik bahan pengikat

$$
\begin{gathered}
\text { Interval SNI } \\
3,00 \%-5,00 \% \\
<\text { No.3 } \\
0,20 \%-6,00 \% \\
1,60-3,20 \\
0,20 \%-2,00 \% \\
1400-1900 \mathrm{~kg} / \mathrm{m}^{3} \\
1400-1900 \mathrm{~kg} / \mathrm{m}^{3} \\
2,20-3,10
\end{gathered}
$$

\begin{tabular}{ccc}
\hline Karakteristik & Hasil & Interval SNI \\
\hline $\begin{array}{c}\text { Berat Jenis } \\
\text { Semen } \\
\begin{array}{c}\text { Berat Jenis } \\
\text { Limbah Karbit }\end{array}\end{array}$ & 3,15 & $3,00-3,20$ \\
\hline
\end{tabular}

\section{Hasil Pemeriksaan Kuat Tekan Beton}

Prosedur pengujian dilaksanakan berdasarkan (SNI 1974-2011). Pengujian dilakukan pada saat benda uji

\begin{tabular}{|c|c|c|c|c|c|}
\hline Variasi & Umur (Hari) & $\begin{array}{l}\text { Beban Maksimim } \\
(\mathrm{KN})\end{array}$ & $\begin{array}{c}\text { Kuat Tekan } \\
\text { Beton Aktual } \\
(\mathrm{MPa})\end{array}$ & $\begin{array}{c}\text { Kuat Tekan Beton } \\
\text { Katual Rata-Rata } \\
\text { (MPa) }\end{array}$ & $\mathrm{F}^{\prime} \mathrm{cr}$ \\
\hline \multirow{15}{*}{ LK 0\% } & \multirow{3}{*}{3} & 230 & 13.02 & \multirow{3}{*}{12.07} & \multirow{3}{*}{13.65} \\
\hline & & 220 & 12.45 & & \\
\hline & & 190 & 10.75 & & \\
\hline & \multirow{3}{*}{7} & 330 & 18.67 & \multirow{3}{*}{18.11} & \multirow{3}{*}{18.87} \\
\hline & & 320 & 18.11 & & \\
\hline & & 310 & 17.54 & & \\
\hline & \multirow{3}{*}{14} & 480 & 27.16 & \multirow{3}{*}{26.41} & \multirow{3}{*}{27.57} \\
\hline & & 470 & 26.6 & & \\
\hline & & 450 & 25.46 & & \\
\hline & \multirow{3}{*}{21} & 530 & 29.99 & \multirow{3}{*}{29.61} & \multirow{3}{*}{30.05} \\
\hline & & 520 & 29.43 & & \\
\hline & & 520 & 29.43 & & \\
\hline & \multirow{3}{*}{28} & 600 & 33.95 & \multirow{3}{*}{33.95} & \multirow{3}{*}{35.47} \\
\hline & & 580 & 32.82 & & \\
\hline & & 620 & 35.08 & & \\
\hline
\end{tabular}
berumur 3 hari, 7 hari, 14 hari, 21 hari, dan 28 hari dengan menggunakan Compression Testing Machine. Pengujian kuat tekan dirancang untuk mengetahui kekuatan beton saat dikenai beban tekan dalam satuan KN. Berikut hasil perhitungan kuat tekan beton berdasarkan perubahan $0 \%, 4 \%$, $6 \%$ dan $8 \%$ dari jumlah limbah karbit.

Tabel 9. hasil pengujian kuat tekan beton limbah karbit $0 \%$ 
Tabel 10. Hasil pengujian kuat tekan beton limbah karbit 4\%

\begin{tabular}{|c|c|c|c|c|c|}
\hline Variasi & Umur (Hari) & $\begin{array}{l}\text { Beban } \\
\text { Maksimim } \\
(\mathrm{KN})\end{array}$ & $\begin{array}{l}\text { Kuat Tekan Beton } \\
\text { Aktual (MPa) }\end{array}$ & $\begin{array}{c}\text { Kuat Tekan Beton } \\
\text { Katual Rata-Rata } \\
\text { (MPa) }\end{array}$ & $\mathrm{F}^{\prime} \mathrm{cr}$ \\
\hline \multirow{15}{*}{ LK 4\% } & \multirow{3}{*}{3} & 250 & 14.15 & \multirow{3}{*}{14.43} & \multirow{3}{*}{14.81} \\
\hline & & 260 & 14.71 & & \\
\hline & & 255 & 14.43 & & \\
\hline & \multirow{3}{*}{7} & 325 & 18.39 & \multirow{3}{*}{18.49} & \multirow{3}{*}{18.7} \\
\hline & & 330 & 18.67 & & \\
\hline & & 325 & 18.39 & & \\
\hline & \multirow{3}{*}{14} & 480 & 27.16 & \multirow{3}{*}{26.5} & \multirow{3}{*}{27.29} \\
\hline & & 460 & 26.03 & & \\
\hline & & 465 & 26.31 & & \\
\hline & \multirow{3}{*}{21} & 510 & 28.86 & \multirow{3}{*}{29.8} & \multirow{3}{*}{30.96} \\
\hline & & 530 & 29.99 & & \\
\hline & & 540 & 30.56 & & \\
\hline & \multirow{3}{*}{28} & 655 & 37.07 & \multirow{3}{*}{35.56} & \multirow{3}{*}{37.64} \\
\hline & & 630 & 35.65 & & \\
\hline & & 600 & 33.95 & & \\
\hline
\end{tabular}

Tabel 11. Hasil pengujian kuat tekan beton limbah karbit $6 \%$

\begin{tabular}{|c|c|c|c|c|c|}
\hline Variasi & Umur (Hari) & $\begin{array}{l}\text { Beban Maksimim } \\
(\mathrm{KN})\end{array}$ & $\begin{array}{l}\text { Kuat Tekan } \\
\text { Beton Aktual } \\
\text { (MPa) }\end{array}$ & $\begin{array}{c}\text { Kuat Tekan } \\
\text { Beton Katual } \\
\text { Rata-Rata } \\
(\mathrm{MPa})\end{array}$ & $\mathrm{F}^{\prime} \mathrm{cr}$ \\
\hline \multirow{15}{*}{ LK 6\% } & \multirow{3}{*}{3} & 180 & 10.19 & \multirow{3}{*}{10.56} & \multirow{3}{*}{11} \\
\hline & & 190 & 10.75 & & \\
\hline & & 190 & 10.75 & & \\
\hline & \multirow{3}{*}{7} & 280 & 15.84 & \multirow{3}{*}{15.94} & \multirow{3}{*}{16.16} \\
\hline & & 280 & 15.84 & & \\
\hline & & 285 & 16.13 & & \\
\hline & \multirow{3}{*}{14} & 355 & 20.09 & \multirow{3}{*}{22.54} & \multirow{3}{*}{25.39} \\
\hline & & 420 & 23.77 & & \\
\hline & & 420 & 23.77 & & \\
\hline & \multirow{3}{*}{21} & 440 & 24.9 & \multirow{3}{*}{26.5} & \multirow{3}{*}{29.59} \\
\hline & & 450 & 25.46 & & \\
\hline & & 515 & 29.14 & & \\
\hline & \multirow{3}{*}{28} & 530 & 29.99 & \multirow{3}{*}{28.86} & \multirow{3}{*}{33.6} \\
\hline & & 440 & 24.9 & & \\
\hline & & 560 & 31.69 & & \\
\hline
\end{tabular}

Tabel 12. Hasil pengujian kuat tekan beton limbah karbit $8 \%$

\begin{tabular}{|c|c|c|c|c|c|}
\hline Variasi & Umur (Hari) & $\begin{array}{l}\text { Beban Maksimim } \\
(\mathrm{KN})\end{array}$ & $\begin{array}{l}\text { Kuat Tekan } \\
\text { Beton Aktual } \\
\text { (MPa) }\end{array}$ & $\begin{array}{c}\text { Kuat Tekan } \\
\text { Beton Katual } \\
\text { Rata-Rata (MPa) }\end{array}$ & $\mathrm{F}^{\prime} \mathrm{cr}$ \\
\hline \multirow{9}{*}{ LK 8\% } & \multirow{3}{*}{3} & 215 & 12.17 & \multirow{3}{*}{10.85} & \multirow{3}{*}{12.56} \\
\hline & & 190 & 10.75 & & \\
\hline & & 170 & 9.62 & & \\
\hline & \multirow{3}{*}{7} & 240 & 13.58 & \multirow{3}{*}{15.94} & \multirow{3}{*}{19.62} \\
\hline & & 270 & 15.28 & & \\
\hline & & 335 & 18.96 & & \\
\hline & \multirow{3}{*}{14} & 390 & 22.07 & \multirow{3}{*}{22.45} & \multirow{3}{*}{25.89} \\
\hline & & 355 & 20.09 & & \\
\hline & & 445 & 25.18 & & \\
\hline
\end{tabular}




\begin{tabular}{llccc}
\hline \multirow{2}{*}{21} & 415 & 23.48 & & \\
& 410 & 23.2 & 24.99 & 28.83 \\
& 500 & 28.29 & & \\
\multirow{2}{*}{28} & 585 & 33.1 & & \\
& 440 & 24.9 & 29.33 & 35.48 \\
\hline
\end{tabular}

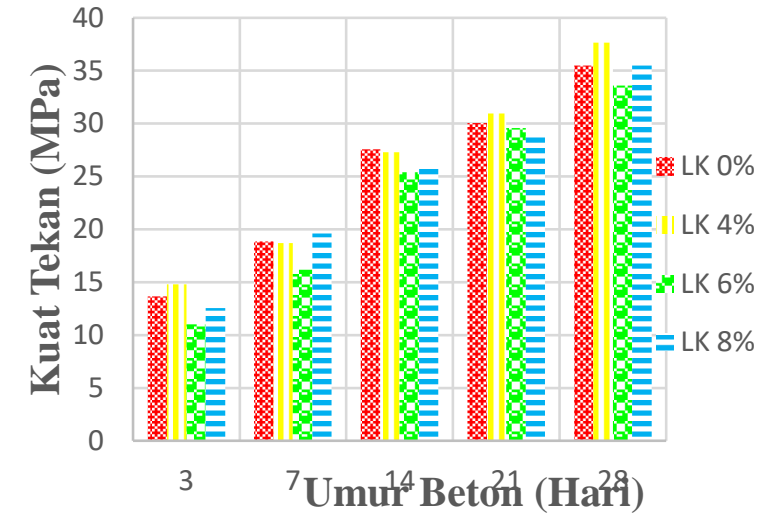

Gambar 4. Hasil pengujian kuat tekan beton terhadap umur beton

Berdasarkan gambar 11, Menunjukkan bahwa kuat tekan beton dari beberapa variasi limbah karbit semakin meningkat seiiring bertambahnya umur beton.

\section{Hasil Pemeriksaan Kuat Tarik Belah Beton}

Pengujian kuat tarik belah beton bertujuan untuk mengetahui gaya tarik maksimum yang diberikan pada beton dalam satuan KN. Setelah mencapai umur perlakuan yang direncanakan yaitu 28 hari, masing-masing sampel dibagi sesuai dengan perubahan substitusi limbah garam kalium yang digunakan, kemudian dilakukan uji tarik belah di laboratorium.

Tabel 13. Hasil pengujian kuat tarik belah beton

\begin{tabular}{cccc}
\hline $\begin{array}{c}\text { Variasi } \\
\text { Limbah } \\
\text { Kabit }\end{array}$ & $\begin{array}{c}\text { Kuat } \\
\text { Tarik } \\
\text { Belah } \\
\text { Aktual } \\
(\mathrm{KN})\end{array}$ & $\begin{array}{c}\text { Kuat Tarik } \\
\text { Belah } \\
\text { Aktual } \\
\text { Rata-rata } \\
(\mathrm{MPa})\end{array}$ & $\begin{array}{c}\text { Kuat Tarik } \\
\text { Belah } \\
\text { Aktual } \\
\text { Rata-rata } \\
(\mathrm{MPa})\end{array}$ \\
\hline \multirow{3}{*}{$0 \%$} & 195 & 2,76 & \\
& 170 & 2,41 & 2,59 \\
& 185 & 2,62 & \\
$4 \%$ & 180 & 2,55 & \\
& 185 & 2,62 & 2,66 \\
\hline
\end{tabular}

\begin{tabular}{llll}
\hline & 185 & 2,62 & \\
$6 \%$ & 165 & 2,33 & 2,50 \\
& 180 & 2,55 & \\
& 175 & 2,48 & \\
$8 \%$ & 170 & 2,40 & 2,50 \\
& 185 & 2,62 & \\
\hline
\end{tabular}

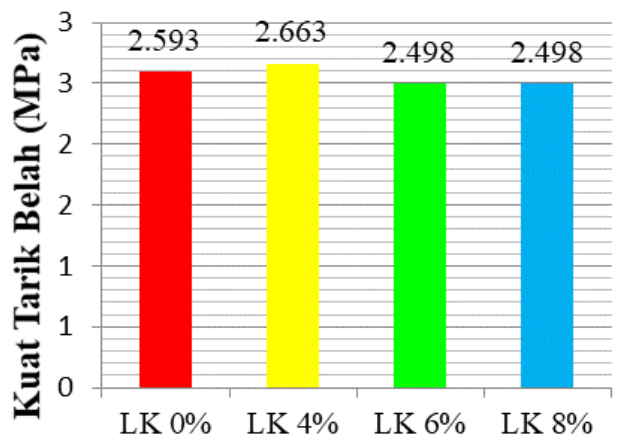

Variasi Limbah Karbit (\%)

Gambar 5. Hubungan variasi limbah karbit terhadap kuat tarik belah beton pada umur 28 Hari

Berdasarkan gambar 5, dapat disimpulkan bahwa kuat tarik belah terbesar pada substitusi limbah karbit $4 \%$ yaitu 2,66 MPa dimana hasil tersebut melebihi hasil kuat tarik belah pada persentasi limbah karbit $0 \%$ yaitu $2,59 \mathrm{MPa}$ dengan kenaikan 2,70\%. Namun dapat dilihat disini bahwa semakin banyak limbah karbit akan menurunkan nilai kuat tarik.

\section{Hasil Pengujian Modulus Elastisitas Beton}

Prosedur pengujian dilaksanakan berdasarkan (SNI 03-4196-1996) ASTM C469. Pengujian ini bertujuan untuk mengetahui besarnya beban yang dapat dipikul tanpa merusak beton itu sendiri (masih dalam keadaan plastis). Pengujian modulus elastisitas beton dilakukan pada umur beton 28 hari. Berikut merupakan hasil perhitungan modulus elastisitas beton dari variasi subtitusi limbah karbit $0 \%, 4 \%, 6 \%$ dan $8 \%$. 
Tabel 14 Hasil perhitungan modulus elastisitas beton

\begin{tabular}{|c|c|c|c|c|c|}
\hline Variasi & $\begin{array}{l}\text { Kode Benda } \\
\text { Uji }\end{array}$ & $\begin{array}{c}\text { Modulus } \\
\text { Elastis (MPa) }\end{array}$ & $\begin{array}{c}\text { Rata-Rata } \\
\text { Modulus } \\
\text { Elastis (MPa) }\end{array}$ & $\begin{array}{c}\text { Modulus } \\
\text { Elastis Teoritis } \\
\left(4700 \sqrt{ } f^{\prime} c\right)\end{array}$ & $\begin{array}{c}\text { Rata-Rata } \\
\text { Modulus } \\
\text { Elastis Teoritis } \\
\left(4700 \sqrt{ } f^{\prime} c\right) \\
\end{array}$ \\
\hline \multirow{4}{*}{ LK 0\% } & SPKT A1 & 18042,45 & \multirow{4}{*}{16957,76} & 27386.55 & \multirow{4}{*}{27384.01} \\
\hline & SPKT A2 & 16978,43 & & 26926.24 & \\
\hline & SPKT A3 & 15852,39 & & 27839.25 & \\
\hline & SPKT B1 & 17175,78 & & 28614.25 & \\
\hline \multirow[t]{3}{*}{ LK 4\% } & SPKT B2 & 16945,50 & \multirow[t]{3}{*}{17180,87} & 28062.86 & \multirow[t]{3}{*}{28021.22} \\
\hline & SPKT B3 & 17421,33 & & 27386.55 & \\
\hline & SPKT C1 & 17405,77 & & 25739.47 & \\
\hline \multirow[t]{3}{*}{ LK 6\% } & SPKT C2 & 16191,11 & \multirow{3}{*}{16635,53} & 23452.44 & \multirow[t]{3}{*}{25216.61} \\
\hline & SPKT C3 & 16309,70 & & 26457.92 & \\
\hline & SPKT D1 & 18345,57 & & 27042.05 & \\
\hline \multirow[t]{2}{*}{ LK 8\% } & SPKT D2 & 12856,45 & \multirow[t]{2}{*}{16429,19} & 23452.44 & \multirow[t]{2}{*}{25411,32} \\
\hline & SPKT D3 & 18085,54 & & 25739,47 & \\
\hline
\end{tabular}

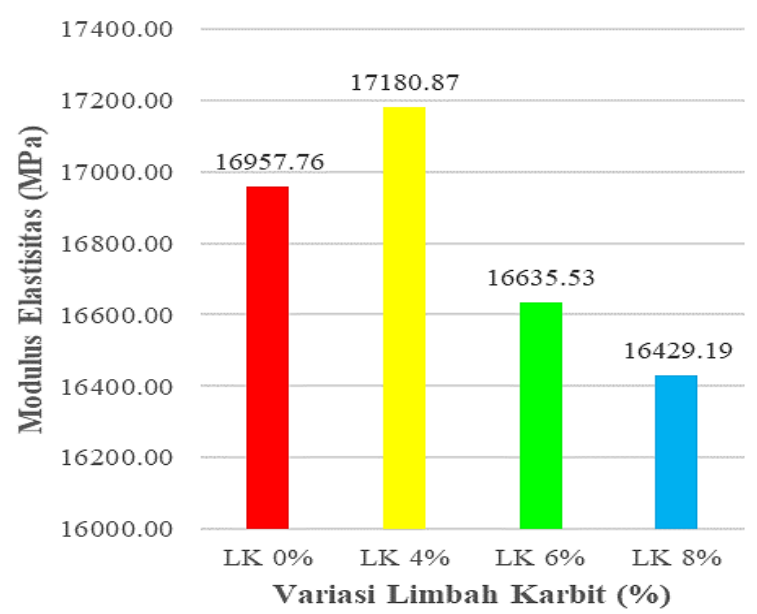

Gambar 6. Hubungan variasi limbah karbit terhadap modulus elastisitas beton

Berdasarkan gambar 6, dapat disimpulkan bahwa modulus elastisitas terbesar pada substitusi limbah karbit $4 \%$ yaitu $17180,87 \mathrm{MPa}$ dimana hasil tersebut melebihi hasil kuat tarik belah pada persentasi limbah karbit 0\% yaitu 15957,76 MPa. Namun dapat dilihat bahwa semakin banyak limbah karbit yang ditambahkan maka semakin rendah modulus elastisitasnya.

Berdasarkan gambar 7 , hubungan tegangan dan regangan pada variasi $0 \%$ terjadi tegangan maksimum sebesar $33.58 \mathrm{MPa}$ dengan nilai regangan 0.0018 , pada variasi $4 \%$ terjadi tegangan maksimum sebesar $34,52 \mathrm{MPa}$ dengan nilai regangan 0.0016 , pada variasi $6 \%$ terjadi tegangan maksimum sebesar 29,99 $\mathrm{MPa}$ dengan nilai regangan 0.0015 , dan pada variasi $8 \%$ terjadi tegangan maksimum sebesar $30,70 \mathrm{MPa}$ dengan nilai regangan 0.0016 .

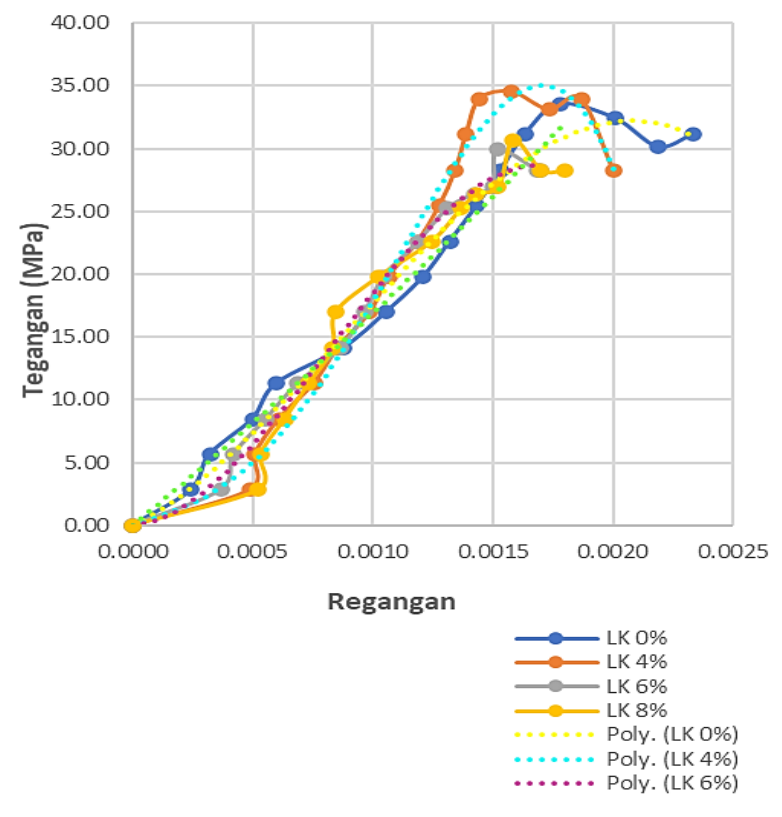

Gambar 7. Hubungan antara tegangan dan regangan

\section{KESIMPULAN}

Pengaruh kekuatan beton yang menggunakan limbah karbit sebagai bahan substitusi semen dengan variasi $0 \%, 4 \%, 6 \%$, dan $8 \%$ diperoleh nilai kuat tekan optimum pada variasi $4 \%$ yakni sebesar $37,645 \mathrm{MPa}$, nilai kuat tarik belah beton optimum pada variasi $4 \%$ yakni sebesar $2,663 \mathrm{MPa}$, dan nilai modulus elastisitas optimum pada variasi $4 \%$ yakni sebesar 17180,87 MPa. Dari hasil penelitian ini dapat dilihat bahwa limbah karbit dapat mempengaruhi kekuatan beton baik itu pada uji kuat tekan, tarik belah, dan modulus elastisitas. 
Komposisi campuran beton dengan menggunakan limbah karbit sebagai bahan substitusi semen diperoleh nilai perbandingan semen, pasir, dan kerikil sebesar $1: 1,61: 3,34$, dengan berat limbah karbit $14,30 \mathrm{~kg}$.

\section{DAFTAR PUSTAKA}

[1] N. R. Dewi, D. Dermawan, dan M. L. Ashari, "Studi Pemanfaatan Limbah B3 Karbit Dan Fly Ash Sebagai Bahan Campuran Beton Siap Pakai (BSP) (Studi Kasus : Pt. Varia Usaha Beton," J. PRESIPITASI, vol. 13, no. 1, hlm. 34-43, 2016.

[2] L. F. Aprida, D. Dermawan, dan R. Bayuaji, "Identifikasi Potensi Pemanfaatan Limbah Karbit dan Abu Sekam Padi sebagai Bahan Alternatif Pengganti Semen," Surabaya, hlm. 13-16.

[3] H. Taufik, Z. Djauhari, M. Sebayang, dan M. Muhandis, "Pengaruh Substitusi Limbah Karbit Terhadap Karakteristik Beton," J. Sainstek STT, vol. 5, no. 1, hlm. 38-43.

[4] F. A. Ultann dan Y. Risdianto, "Pemanfaatan Limbah Karbit Sebagai Bahan Pengganti (Substitusi) Semen Pada Pembuatan Beton Ringan Seluler (Cellular Lightweight
Concrete)," Rekayasa Tek. Sipil, vol. 1, no. 1, hlm. 1-7, 2020.

[5] K. Tjokrodimuljo, Teknologi Beton. Yogyakarta: Biro Penerbit KMTS FT UGM, 2007.

[6] K. S. Suwindu, H. Parung, dan D. Sandy, "Karakteristik Beton Mutu Tinggi dengan Substitusi Slag Baja dan Slag Nikel Sebagai Agregat Kasar," Paulus Civ. Eng. J., vol. 2, no. 1, hlm. 8-15, 2020.

[7] T. Mulyono, Teknologi Beton: Dari Teori Ke Praktek, 1 ed. Jakarta: Lembaga Pengembangan Pendidikan - UNJ, 2015.

[8] I. BSN, "Tata Cara Pembuatan Rencana Campuran Beton Normal SNI 03-2834-2000." Badan Standarisasi Nasional, 2000.

[9] A. C. Posedung, F. Phengkarsa, dan D. Sandy, "Pemanfaatan Bottom Ash Sebagai Bahan Substitusi Agregat Halus Terhadap Kekuatan Beton," Paulus Civ. Eng. J., vol. 2, no. 3, hlm. 187-195, 2020.

[10] Y. E. Prasetyo dan S. Widodo, "Pengaruh Cara Perawatan Terhadap Kuat Tekan dan Kuat Lentur," INERSIA, vol. XI, no. 1, hlm. 46-52, 2015. 